CONSTANTINE AND ROME 



\section{Constantine Rome}

R. ROSS HOLLOWAY

Yale University Press New Haven and London 
Copyright $(2) 2004$ by Yale University. All rights reserved. This book may not be reproduced, in whole or in part, including illustrations, in any form (beyond that copying permitted by Sections 107 and 108 of the U.S. Copyright Law and except by reviewers for the public press), without written permission from the publishers.

Designed by Rebecca Gibb. Set in Adobe Minion by Duke \& Company, Devon, Pennsylvania. Printed in the United States of America by Sheridan Books, Ann Arbor, Michigan.

Library of Congress Cataloging-in-Publication Data

Holloway, R. Ross, 1934-

Constantine and Rome / R. Ross Holloway.

p. $\mathrm{cm}$.

Includes bibliographical references and index.

ISBN 0-300-10043-4 (alk. paper)

1. Architecture, Early Christian-Italy—Rome. 2. Architecture-Italy-Rome. 3. Constantine I, Emperor of Rome, d. 337-Art patronage. 4. Christianity and art—Italy—Rome. 5. Rome (Italy)—Buildings, structures, etc. I. Title.

NA5620.A1H65 2004

$722^{\prime} .7-\mathrm{dc} 22$

2003018712

A catalogue record for this book is available from the British Library.

The paper in this book meets the guidelines for permanence and durability of the Committee on Production Guidelines for Book Longevity of the Council on Library Resources.

$1098 \begin{array}{lllllll}10 & 9 & 5 & 4 & 3 & 2 & 1\end{array}$ 
G V G L I E L O L OV E L A C E

SERVIENTI AD LEGEM

OCTOVIRO VERAE RELIGIONI RESTITVENDAE A D MDLIX

AEVO AVCTOR 
